\title{
Production of lactic acid by respiratory muscles
}

\author{
S FREEDMAN, NT COOKE, J MOXHAM \\ From the Respiratory Department, University College Hospital Medical School, London
}

ABSTRACT We measured blood lactate in normal subjects after 10 minutes of sustained maximum voluntary ventilation (SMVV) with end-tidal $\mathrm{PCO}_{2}$ kept constant and after breathing against a big added respiratory load for 200 breaths. With SMVV subjects sustained on average $68 \%$ of the predicted maximum breathing capacity and achieved final lactate concentrations of $1.9 \mathrm{mmol} / \mathrm{l}$ $(17.1 \mathrm{mg} / 100 \mathrm{ml})$, representing an average increase of about $1.0 \mathrm{mmol} / 1(9.0 \mathrm{mg} / 100 \mathrm{ml})$ over resting values. There was a wide range between individuals, from no increase at all to $2.7 \mathrm{mmol} / \mathrm{l}$, despite similar levels of ventilation. Breathing against added loads produced much smaller changes in blood lactate.

Fatigue of the respiratory muscles is potentially a major factor in the development of respiratory failure. ${ }^{1}$ Underlying this fatigue is thought to be a failure of substrate supply to the contracting muscles. This would be expected to produce a switch to anaerobic metabolism with production of lactic acid, but previous attempts to show an increase in systemic blood lactate due simply to breathing have been unsuccessful in both normal subjects ${ }^{2}$ and patients with airways obstruction ${ }^{3}$ in the absence of concomitant systemic hypoxaemia or circulatory failure. We have re-examined this problem in normal subjects by measuring systemic blood lactate concentrations before and after sustained maximum voluntary ventilation (SMVV) and before and after breathing through resistances, both of which have been shown to produce evidence of fatigue in the diaphragm, intercostals, and accessory muscles. ${ }^{4-7}$ A brief report of this work has previously been published. ${ }^{8}$

\section{Methods}

The seven subjects, all men, were laboratory personnel and doctors who were aware of the nature and purpose of the investigation. In experiments concerned with sustained maximum voluntary ventilation the subjects breathed as hard as possible for 10 minutes. A target respiratory frequency was set at 60 breaths/min by a metronome and the subjects were continuously exhorted to breathe as deeply as possible. To prevent hypocapnia we used the circuit described by Eger et al, ${ }^{9}$ in which carbon dioxide is

Address for reprint requests: Dr S Freedman, Chase Farm Hospital, Enfield, Middlesex EN2 8JL. continuously added at a rate controlled by the exper-imenter to maintain end-tidal carbon dioxide ten- $\vec{\varphi}$ sion $\left(\mathrm{PCO}_{2}\right)$ at any desired level. End-tidal carbon dioxide was continuously measured with a Capnograph (Godart) and the aim was to maintain it at about $40 \mathrm{~mm} \mathrm{Hg}(5 \cdot 3 \mathrm{kPa})$. Ventilation was measured by means of a pneumotachograph and integrator. The experiments were carried out with the $\Phi$ subjects semi-recumbent, to minimise work associ- $\vec{F}$ ated with maintenance of posture and to facilitate blood sampling. This was done with an indwelling venous cannula, inserted into a vein on the back of $\vec{F}$ the hand. The hand was kept wrapped in an electrically heated pad maintained at about $60^{\circ} \mathrm{C}$. Samples were drawn into heparinised syringes for analysis of pH and blood gases on Radiometer electrodes and $\dot{\sigma}$ into plain syringes for lactate and pyruvate meas- 3 . urements. These were drawn quickly and immediately transferred into preweighed tubes containing ice-cold perchloric acid, with which they were 0 thoroughly mixed. Subsequently they were analysed by the method of Lloyd et al. ${ }^{10}$ The accuracy of the $\frac{D}{0}$ method was such that the coefficient of variation for repeat measurements on samples was $3 \%$ for lac- $\tilde{\sigma}$ tate. Pyruvate was measured manually by an $N$ enzymatic method, with a coefficient of variation of $N$ $11 \%$.

Two resting samples were drawn, at an interval of five minutes with the subject breathing quietly into $\stackrel{\varrho}{=}$ the circuit. After the second of these SMVV was $\stackrel{\infty}{\rightarrow}$ started, and further samples were drawn after five and 10 minutes, after which the subject stopped 0 SMVV. Two more blood samples were taken, after $\stackrel{\mathbb{D}}{\circ}$ 10 and 20 minutes respectively of the recovery phase. 
Standard spirometry was carried out on all subjects on a "Floop" apparatus (Oldelft) and a Wright peak flow meter was used after an experiment to check that the hyperventilation did not induce bronchoconstriction. All subjects were studied once and five of them a second or third time, either because $\mathrm{PCO}_{2}$ was inadequately controlled on the first run or because we wished to assess the reproducibility of the results.

Four subjects subsequently did experiments in which they breathed through an inspiratory and an expiratory resistance. The resistance was simply a hole in a bung, of a diameter such that the subjects were able to produce mouth pressures which were at least $70 \%$ of their maximum static mouth pressures on every breath. The resistance was mounted on either the inspiratory or the expiratory side of a valve box while the subject breathed air. Mouth pressures were measured with a Hewlett Packard 267B transducer. Ventilation and end-tidal $\mathrm{PCO}_{2}$ were measured from the free limb of the valve box with the equipment described above. The subjects sat upright for these experiments and breathed through the resistance for 200 breaths at any frequency they liked, the experiment usually lasting 10-20 minutes. Blood samples were again drawn from a heated hand vein. Two samples were drawn at rest, one immediately after completion of the 200 breaths and two more after 10 and 20 minutes of the recovery phase.

\section{Results}

SMVV

For these experiments we set arbitrary limits on arterialised blood $\mathrm{PCO}_{2}$ of $35-45 \mathrm{~mm} \mathrm{Hg}(4 \cdot 7-6 \mathrm{kPa})$ and rejected data from any experiments in which these were not met. Variation of $\mathrm{PCO}_{2}$ within these limits would be expected to have a negligible effect

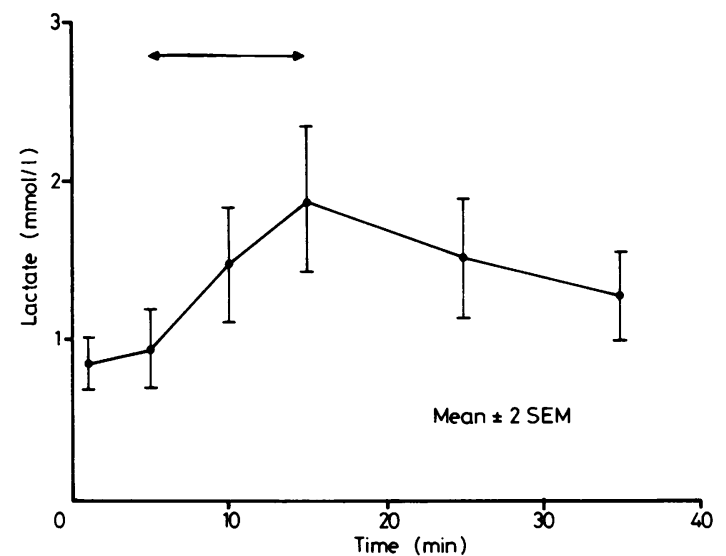

Fig 1 Changes in blood lactate before, during, and after 10 minutes of sustained maximum voluntary ventilation (means of 11 experiments in seven subjects). The arrowed line indicates the period of maximum voluntary ventilation. Conversion: SI to traditional units-lactate: $1 \mathrm{mmol} / \mathrm{l}=$ $9.0 \mathrm{mg} / 100 \mathrm{ml}$.

on lactate or pyruvate concentrations. ${ }^{11}$ Mean changes in blood lactate from the 11 experiments which fulfilled these criteria are given in figure 1 and individual data in table 1 , where results are shown from the experiment in which each subject achieved his highest ventilation.

The average increase in lactate after 10 minutes' SMVV was $1.10 \mathrm{mmol} / \mathrm{l}(9.9 \mathrm{mg} / 100 \mathrm{ml})(\mathrm{p}<0.01$ on paired $t$ test), but there was wide variation between individuals-from no increase at all to one of $2.7 \mathrm{mmol} / \mathrm{l}(24.3 \mathrm{mg} / 100 \mathrm{ml})$. These results were individually consistent-for example, subject No 5 had a similar increase on a repeat experiment and No 7, in a second experiment with an almost identical ventilation, again had a high resting lactate and no increase after SMVV.

There was no correlation between increase in lac-

Table 1 Changes in blood lactate and pyruvate after sustained maximum voluntary ventilation (SMVV)

\begin{tabular}{|c|c|c|c|c|c|c|c|c|c|c|c|}
\hline \multirow[t]{3}{*}{ Subject No } & \multicolumn{3}{|c|}{$S M V V$} & \multicolumn{4}{|c|}{ Lactate ( $\mathrm{mmol} / \mathrm{l})$} & \multicolumn{4}{|c|}{ Pyruvate (mmol/l) } \\
\hline & \multirow[t]{2}{*}{$l / \min$} & \multirow{2}{*}{$\begin{array}{l}\text { \% pred } \\
M B C^{*}\end{array}$} & \multirow{2}{*}{$\begin{array}{l}\mathrm{PCO}_{2} \text { at } \\
10 \mathrm{~min} \\
(\mathrm{~mm} \mathrm{Hg}) \dagger\end{array}$} & \multicolumn{2}{|l|}{ Rest } & \multicolumn{2}{|c|}{$S M V V(\min )$} & \multicolumn{2}{|l|}{ Rest } & \multicolumn{2}{|c|}{$S M V V(\min )$} \\
\hline & & & & $I$ & 2 & 5 & 10 & 1 & 2 & 5 & 10 \\
\hline $\begin{array}{l}1 \\
2 \\
3 \\
4 \\
5 \\
6 \\
7\end{array}$ & $\begin{array}{r}112 \\
82 \\
124 \\
112 \\
110 \\
114 \\
111\end{array}$ & $\begin{array}{l}66 \\
56 \\
65 \\
76 \\
69 \\
90 \\
59\end{array}$ & $\begin{array}{l}41 \\
45 \\
39 \\
44 \\
42 \\
36 \\
37\end{array}$ & $\begin{array}{l}0.64 \\
0.66 \\
0.92 \\
0.73 \\
0.63 \\
1.04 \\
1.26\end{array}$ & $\begin{array}{l}0.58 \\
0.67 \\
0.85 \\
0.72 \\
0.53 \\
1.03 \\
1.17\end{array}$ & $\begin{array}{l}0.83 \\
1.41 \\
1.33 \\
1.28 \\
3.02 \\
1.76 \\
1.11\end{array}$ & $\begin{array}{l}1.17 \\
2.43 \\
0.78 \\
2.28 \\
3.28 \\
2.25 \\
1.20\end{array}$ & $\begin{array}{l}0.02 \\
0.03 \\
0.08 \\
0.01 \\
0.02 \\
0.10 \\
0.04\end{array}$ & $\begin{array}{l}0.02 \\
0.06 \\
0.09 \\
0.01 \\
0.01 \\
0.09 \\
0.03\end{array}$ & $\begin{array}{l}0.03 \\
0.04 \\
0.08 \\
0.02 \\
0.02 \\
0.09 \\
0.03\end{array}$ & $\begin{array}{l}0.04 \\
0.03 \\
0.10 \\
0.04 \\
0.03 \\
0.12 \\
0.04\end{array}$ \\
\hline $\begin{array}{l}\text { Mean } \\
\text { SEM }\end{array}$ & $\begin{array}{r}108 \cdot 6 \\
4.9\end{array}$ & $\begin{array}{r}68 \cdot 7 \\
4 \cdot 3\end{array}$ & $\begin{array}{r}40.5 \\
1.3\end{array}$ & $\begin{array}{l}0.84 \\
0.09\end{array}$ & $\begin{array}{l}0.79 \\
0.09\end{array}$ & $\begin{array}{l}1.53 \\
0.27\end{array}$ & $\begin{array}{l}1.91 \\
0.33\end{array}$ & $\begin{array}{l}0.043 \\
0.011\end{array}$ & $\begin{array}{l}0.044 \\
0.013\end{array}$ & $\begin{array}{l}0.044 \\
0.011\end{array}$ & $\begin{array}{l}0.057 \\
0.014\end{array}$ \\
\hline
\end{tabular}

*\%pred $\mathrm{MBC}=$ percentage of predicted maximum breathing capacity $(\mathrm{FEV}, \times 35) . \dagger 1 \mathrm{~mm} \mathrm{Hg} \approx 0 \cdot 13 \mathrm{kPa}$.

Conversion: Traditional units to $\mathrm{SI}-\mathrm{PCO}_{2}: 1 \mathrm{~mm} \mathrm{Hg} \approx 0.13 \mathrm{kPa}$. SI to traditional units-lactate: $1 \mathrm{mmol} / 1=9.0 \mathrm{mg} / 100 \mathrm{ml}$. Pyruvate: 1 $\mathrm{mmol} / 1 \approx 8.8 \mathrm{mg} / 100 \mathrm{ml}$. 
tate and ventilation, whether expressed in absolute terms or standardised for age and height as a percentage of predicted maximum breathing capacity $\left(\mathrm{FEV}_{1 \cdot 0} \times 35\right)$. There was also no correlation between $\mathrm{PCO}_{2}$ and lactate. There was a close correlation between change in blood lactate and change in blood $\mathrm{H}^{+}$, as shown in figure 2 , which includes data after five and 10 minutes' SMVV. The correlation coefficient, $r$, was 0.73 .

There were no significant changes in pyruvate concentrations in any experiment.

\section{ADDED LOADS}

Increases in blood lactate after 200 loaded breaths were much smaller (table 2), averaging $0.10 \mathrm{mmol} / \mathrm{l}$ $(0.9 \mathrm{mg} / 100 \mathrm{ml})$ for inspiratory loads and 0.22 $\mathrm{mmol} / \mathrm{l}(1.98 \mathrm{mg} / 100 \mathrm{ml})$ for expiratory loads. There was again wide individual variation, from no change in subject No 6 to an increase of $0.53 \mathrm{mmol} / 1(4.77$ $\mathrm{mg} / 100 \mathrm{ml}$ ) in No 1 . While these changes were, on average, small, they exceed the variability of the method, and the difference between the average of the two resting values and the value after 200 breaths was significant ( $<<0.05$ by paired $t$ or by Wilcoxon rank sum sign test). We had no measurements of blood $\mathrm{pH}$ or $\mathrm{PCO}_{2}$ in these experiments but we did measure end-tidal $\mathrm{PcO}_{2}$ which at the slow respiratory frequencies adopted by the subjects is very close to arterial $\mathrm{PCO}_{2}$. End-tidal $\mathrm{PcO}_{2}$ was within the range $37-45 \mathrm{~mm} \mathrm{Hg}(4.9-6.0 \mathrm{kPa})$ in all experiments. There was a tendency for it to rise $2-3 \mathrm{~mm}$ $\mathrm{Hg}(0.26-0.4 \mathrm{kPa})$ during an experiment but the magnitude of the change is insufficient to cause the increase in blood lactate concentration.

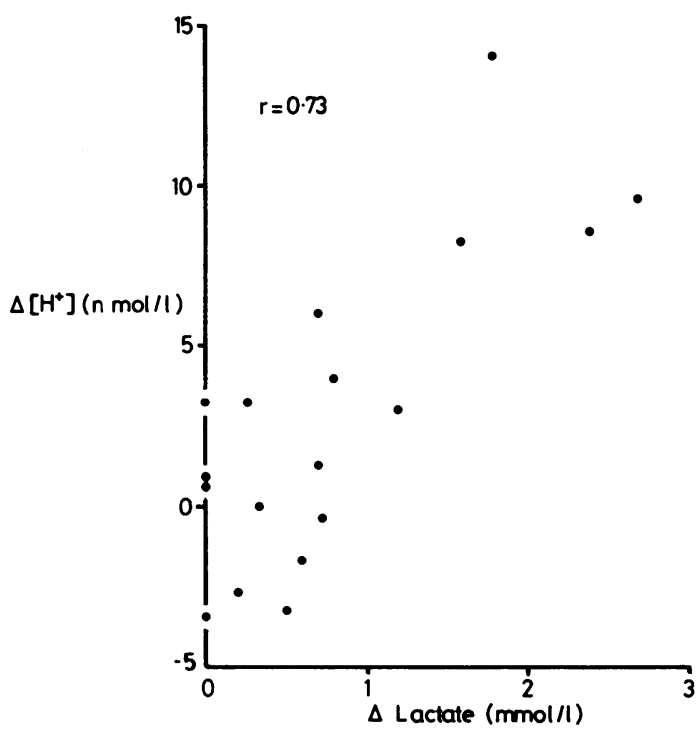

Fig 2 Relationship of change in blood $\left[\mathrm{H}^{+}\right]$from control to sustained maximum voluntary ventilation and corresponding change in blood lactate. The data include values obtained after five and 10 minutes' sustained maximum voluntary ventilation from 11 experiments. Conversion: SI to traditional units-lactate: $1 \mathrm{mmol} / \mathrm{l}=9.0$ $\mathrm{mg} / 100 \mathrm{ml}$.

\section{Discussion}

We have shown a small but significant increase in blood lactate concentrations after 10 minutes' voluntary ventilation at about $70 \%$ of maximum

Table 2 Changes in lactate and pyruvate after loading

\begin{tabular}{|c|c|c|c|c|c|c|c|}
\hline \multirow[t]{2}{*}{ Subject No } & \multirow[t]{2}{*}{ Load } & \multicolumn{3}{|c|}{ Lactate (mmolll) } & \multicolumn{3}{|c|}{ Pyruvate (mmolll) } \\
\hline & & Rest 1 & Rest 2 & $\begin{array}{l}\text { After } 200 \\
\text { breaths }\end{array}$ & Rest 1 & Rest 2 & $\begin{array}{l}\text { After } 200 \\
\text { breaths }\end{array}$ \\
\hline 1 & $\begin{array}{l}\text { Insp } \\
\text { Exp }\end{array}$ & $0 \cdot 86$ & $\begin{array}{l}0.78 \\
0.89\end{array}$ & $\begin{array}{l}1.35 \\
1.06\end{array}$ & $0 \cdot 10$ & $\begin{array}{l}0.08 \\
0.06\end{array}$ & $\begin{array}{l}0.10 \\
0 \cdot 09\end{array}$ \\
\hline 2 & $\begin{array}{l}\text { Insp } \\
\text { Exp }\end{array}$ & $\begin{array}{l}0.77 \\
0.58\end{array}$ & $\begin{array}{l}0.74 \\
0.59\end{array}$ & $\begin{array}{l}0.95 \\
0.96\end{array}$ & $\begin{array}{l}0.02 \\
0.08\end{array}$ & $\begin{array}{l}0.04 \\
0.05\end{array}$ & $\begin{array}{l}0.06 \\
0.02\end{array}$ \\
\hline 4 & $\begin{array}{l}\text { Insp } \\
\text { Exp }\end{array}$ & $\begin{array}{l}0.66 \\
0.61\end{array}$ & $\begin{array}{l}0.60 \\
0.72\end{array}$ & $\begin{array}{l}0.76 \\
0.78\end{array}$ & $\begin{array}{l}0.05 \\
0.03\end{array}$ & $\begin{array}{l}0.04 \\
0.05\end{array}$ & $\begin{array}{l}0.03 \\
0.02\end{array}$ \\
\hline 6 & $\begin{array}{l}\text { Insp } \\
\text { Exp }\end{array}$ & 1.08 & $\begin{array}{l}0.88 \\
0.67\end{array}$ & $\begin{array}{l}0.90 \\
0.89\end{array}$ & $\frac{0.06}{-}$ & $\begin{array}{l}0.07 \\
0.07\end{array}$ & $\begin{array}{l}0.06 \\
0.07\end{array}$ \\
\hline $\begin{array}{l}\text { Mean } \\
\text { Mean }\end{array}$ & $\begin{array}{l}\text { Insp } \\
\text { Exp }\end{array}$ & $\begin{array}{l}0.84 \\
0.60\end{array}$ & $\begin{array}{l}0.75 \\
0.72\end{array}$ & $\begin{array}{l}0.99 \\
0.92\end{array}$ & $\begin{array}{l}0.06 \\
0.05\end{array}$ & $\begin{array}{l}0.06 \\
0.06\end{array}$ & $\begin{array}{l}0.06 \\
0.05\end{array}$ \\
\hline $\begin{array}{l}\text { Overall mean } \\
\text { SEM }\end{array}$ & & $\begin{array}{l}0.76 \\
0.08\end{array}$ & $\begin{array}{l}0.73 \\
0.04\end{array}$ & $\begin{array}{l}0.96 \\
0.07\end{array}$ & $\begin{array}{l}0.05 \\
0.005\end{array}$ & $\begin{array}{l}0.06 \\
0.005\end{array}$ & $\begin{array}{l}0.06 \\
0.011\end{array}$ \\
\hline
\end{tabular}

Insp-inspiratory load; Exp-expiratory load.

Conversion: SI to traditional units-lactate: $1 \mathrm{mmol} / \mathrm{l}=9.0 \mathrm{mg} / 100 \mathrm{ml}$. Pyruvate: $1 \mathrm{mmol} / \mathrm{l} \approx 8.8 \mathrm{mg} / 100 \mathrm{ml}$. 
breathing capacity. This was unaccompanied by any changes in blood pyruvate concentration and with $\mathrm{PCO}_{2}$ maintained within narrow limits the increases in lactate may reasonably be attributed to anaerobic metabolism and not to changes in blood $\mathrm{pH} .{ }^{112}$ Similarly, the small changes in blood pyruvate concentrations make it unlikely that the lactate accumulation was due to catecholamine secretion.

Normally lactate diffuses from its site of production in working muscle to be evenly distributed in the body water and metabolised by certain tissues, particularly liver, heart, and non-working muscle. If we assume even distribution, our experiments showed a net accumulation of about $35 \mathrm{mmol}$ (3150 $\mathrm{mg}$ ) lactate over 10 minutes. Are the respiratory muscles of sufficient bulk to account for this amount of lactate? There do not appear to be any data on the mass of normal human respiratory muscles apart from Marshall's estimate that the diaphragm weighs about 300 g. ${ }^{13}$ Thurlbeck found similar weights in patients with airways obstruction but minimal emphysema. ${ }^{14}$ From the anatomical data quoted by Otis $e a^{15}$ the mass of the intercostals can be estimated at $660 \mathrm{~g}$. Thus the mass of what are conventionally regarded as "respiratory" muscles is about $960 \mathrm{~g}$. This would give a lactate production (if we assume for the moment no lactate consumption elsewhere) of $30 \mu \mathrm{g} / \mathrm{min} / \mathrm{g}$ muscle, a figure well below the rates for the perfused rat diaphragm ${ }^{16}$ and for human exercise. ${ }^{17}$ It is thus feasible that the lactate came from the respiratory muscles.

During maximum voluntary ventilation, however, many muscles other than intercostals and diaphragm are active, including sternomastoids and trapezii, the abdominal muscles, and the muscles of the back. Some of these may be concerned with stabilisation of the chest and maintenance of posture during the respiratory gymnastics of maximum voluntary ventilation, and in this respect it is of interest that the average increase in blood lactate in these experiments when our subjects were semi-recumbent was about half that seen in similar experiments in which the subjects sat upright. ${ }^{18}$

The total muscle mass active during maximum voluntary ventilation is therefore adequate to account for all the lactate accumulation, even though liver metabolism of lactate almost certainly took place during the test. We wondered whether the maximum voluntary ventilation could have decreased liver blood flow and thus lactate metabolism. There is no direct evidence on this in man, but Rowell et $a l^{19}$ have shown that during exercise (upright on a bicycle) there is still a net splanchnic removal of lactate despite a $50-70 \%$ fall in estimated hepatic blood flow. In dogs positive-pressure ventilation, even with a normal $\mathrm{PCO}_{2}$, does decrease liver blood flow in parallel with venous return and cardiac output. ${ }^{20}$

In a further effort to resolve these questions we carried out the experiments with added loads. We thought that these would stress more purely "respiratory" muscles. We also reasoned that the development of big positive intrathoracic pressures with expiratory loads would be more likely to depress venous return and hence liver blood flow than inspiratory loads, with a correspondingly greater increase in blood lactate. The results showed no difference between inspiratory and expiratory loads, with a much smaller but still significant increase in lactate than in the SMVV experiments. This suggests, firstly, that the development of big intrathoracic pressures, either positive or negative, does not diminish hepatic uptake of lactate and, secondly, that a much smaller bulk of muscle was active during loaded breathing than during SMVV.

Recently Jardim $e t a^{21}$ have shown increases in systemic blood lactate of about $0.9-1.8 \mathrm{mmol} / \mathrm{l}$ $(8 \cdot 1-16.2 \mathrm{mg} / 100 \mathrm{ml})$ in four subjects breathing against an inspiratory resistance to the point of demonstrable fatigue of the inspiratory muscles (that is, inability to generate a given pressure). The experiments lasted 12-45 minutes, and their subjects were required to produce $80 \%$ of maximum inspiratory pressure with each breath. This is higher than the target we set and this, together with the much longer duration of their experiments, would explain their greater increases in systemic lactate. Overall rates of accumulation of lactate (final concentration divided by duration of experiment) were fairly similar in their experiments and ours.

Sustained maximum voluntary ventilation produces a significant rise in blood lactate concentration, reflecting the anaerobic metabolism of the respiratory muscles and the many other skeletal muscles vigorously employed during this procedure. The smaller increase in lactate with respiratory loading suggests that the respiratory muscles themselves can produce an increase in lactate because during this procedure other skeletal muscles are not particularly active. Contraction forces that are sufficient to generate significant quantities of lactate are known to be associated with muscle fatigue, and our findings are therefore consistent with the observation that SMVV produces low-frequency fatigue of the respiratory muscles. Although the increase in blood lactate after SMVV is small, it could be a significant addition to the total lactic acidaemia of heavy exercise.

We should like to acknowledge the help of Dr Joan Round and Dr Malcolm Jackson of the department of human metabolism, who did the lactate and pyru- 
vate estimations, and also the technical assistance of Mr A Cobley. We are grateful to Sandoz Ltd for financial support.

\section{References}

${ }^{1}$ Macklem PT. Normal and abnormal function of the diaphragm. Thorax 1981;36:161-3.

${ }^{2}$ Eldridge F. Anaerobic metabolism of the respiratory muscles. J Appl Physiol 1966;21:853-7.

${ }^{3}$ Penman RWB. Blood lactate levels and some blood acid-base changes in respiratory failure and their significance in oxygen induced respiratory depression. Clin Sci 1962;23:5-12.

${ }^{4}$ Roussos CS, Macklem PT. Diaphragmatic fatigue in man. J App Physiol 1977;43:189-97.

${ }^{5}$ Roussos CS, Fixley M, Gross D, Macklem PT. Fatigue of

- the inspiratory muscles and their synergic behaviour. $J$ Appl Physiol 1979;46:897-904.

6 Moxham J, Wiles CM, Newham D, Edwards RHT. Sternomastoid muscle function and fatigue in man. Clin Sci 1980;59:463-8.

${ }^{7}$ Moxham J, Morris AJR, Spiro SG, Edwards RHT, Green M. Contractile properties and fatigue of the diaphragm. Thorax 1981;36:164-8.

${ }^{8}$ Cobley AJ, Cooke NT, Freedman S, Moxham J. Increase in blood lactate following maximum voluntary ventilation. J Physiol (Lond) 1981;315:35P.

9 Eger EI, Kellogg RH, Mines AH, Lima-Ostos M, Morrill CG, Kent DW. Influence of $\mathrm{CO}_{2}$ on ventilatory acclimatization to altitude. $J$ Appl Physiol 1968;24:607-15.

${ }^{10}$ Lloyd B, Burrin J, Smythe P, Alberti KGMM. Simple automated enzymic fluorometric assays for blood glu- cose, lactate, pyruvate, alanine, glycerol and $\stackrel{0}{x}$ 3-hydroxybutyrate. Clin Chem 1978;24:1724-9.

${ }^{11}$ Eldridge F, Salzer J. Effect of respiratory alkalosis on $\stackrel{\oplus}{\hookrightarrow}$ blood lactate and pyruvate in humans. J Appl Physiol 0 1967;22:461-8.

12 Sutton JR, Jones NL, Toews CJ. Effect of pH on muscle $\frac{\overline{\bar{c}}}{\overline{\bar{T}}}$ glycolysis during exercise. Clin Sci 1981;61:331-8.

${ }^{13}$ Marshall R. In: Howell JBL, Campbell EJM, eds. @ Breathlessness. Oxford: Blackwell Scientific Publica- 仓ी tions, 1966:195.

${ }_{14}$ Thurlbeck WM. Diaphragm and body weight in emphysema. Thorax 1978;33:483-7.

${ }^{15}$ Otis AB, Fenn WO, Rahn H. Mechanics of breathing in man. J Appl Physiol 1950;2:592-607.

${ }^{16}$ Hollanders FD. The production of lactic acid by the perfused rat diaphragm. Comp Biochem Physiol 1968;26:907-16.

${ }^{17}$ Margaria R, Cerretelli P, Mangili F. Balance and kinetics of anaerobic energy release during strenuous exercise $\mathrm{O}$ in man. J Appl Physiol 1964;19:623-8.

${ }^{18}$ Freedman $S$. The functional capacity of the respiratory $\vec{c}$ muscles in man. University of London, PhD thesis, 1969.

${ }^{19}$ Rowell LB, Kraning KK, Evans TO, Kennedy JW Blackmon JR, Kusami F. Splachnic removal of lactate during prolonged exercise in man. J Appl Physiol 1966;21:1773-83.

${ }^{20}$ Hughes RL, Mathie RT, Fitch W, Campbell D. Liver blood flow and oxygen consumption during hypocapnia and IPPV in the greyhound. J Appl Physiol 1979;47:290-5.

${ }^{21}$ Jardim J, Farkas G, Prefaut C, Thomas D, Macklem PT, 응 Roussos CH. The failing inspiratory muscles under $\varrho$ normoxic and hypoxic conditions. Am Rev Respir Dis $\overline{\bar{O}}$ 1981;124:274-9. 